\title{
The Acculturation Process and Philanthropic Giving: Evaluating the Effect of Sociocultural Adaptation and Ethnic Identity*
}

\author{
Seong-gin Moon**
}

\begin{abstract}
Although literature on the field of philanthropy has examined why and how individual give, there is a lack of attention paid to the acculturation process that occurs after immigrants' arrival to a host country. This study focuses on two salient parts of the acculturation process - sociocultural adaptation and ethnic identity - and empirically examines their respective effects on giving. Based on data from the Korean-American Philanthropic Survey, regression models are constructed to estimate such effects. The empirical results show that immigrants with a higher level of sociocultural adaptation are more likely to give than their counterparts in terms of both participation and the amount. In addition, immigrants with a stronger Korean identity are more likely to give more than their counterparts. Finally, some resources that immigrants possess are positively related to giving, including education, religiosity, age, and household income.
\end{abstract}

Keywords: acculturation, sociocultural adaptation, ethnic identity, philanthropic giving

\section{INTRODUCTION}

Nonprofit organizations play a vital role in public service delivery at all levels of government. Over the past two decades, they have increasingly shared with government the role of public service provision, which had traditionally been seen as the sole province of government (Salamon, 2002). Nonprofit sectors have also become a conduit for the voluntary involvement of citizens in the process of public service production through donation; thus, nonprofits have the potential to foster a vibrant civic and democratic society.

\footnotetext{
* This research is supported by Inha University.

** Seong-gin Moon is a professor in the Department of Public Administration Inha University. moons@inha.ac.kr.
}

Manuscript received June 21, 2017; out for review July 2, 2017; review completed August 7, 2018; accepted August 10, 2018.

The Korean Journal of Policy Studies, Vol. 33, No. 2 (2018), pp. 53-74.

(C) 2018 by the GSPA, Seoul National University 
The growing responsibilities of nonprofit sectors pose significant institutional challenges that stem from their lack of institutional resources. Among the primary challenge is the sustainability of nonprofits' revenue streams. Many scholars and nonprofit leaders express growing concerns over nonprofits' financial stability. Nonprofits' financial base is eroding, largely due to the decline in individual contribution as a percentage of total income, cutbacks in public funding, and market competition between nonprofit and for-profit organizations (Hodgkinson, 2002; Salamon, 2002).

The thinning of their financial base has led nonprofits to think about how to diversify their revenue streams (Van Slyke et al., 2007). Reaching out to and cultivating donors is one of the important tasks nonprofits need to undertake in order to survive and succeed in the long term. In addition, the involvement of a range of constituents in philanthropy can build a larger community in which diverse groups of people interact and work together to promote collective interests (Putnam, 1995; Uslaner \& Conley, 2003).

Despite the importance of diversifying fundraising efforts, most of these efforts are still directed at the white population in the United States (Newman, 2002). Ethnic minorities are generally viewed as recipients of services rather than potential donors and thus are often overlooked in philanthropic outreach (Newman, 2002). Systematic research that looks at the giving behavior of immigrants in the United States separately from that of the mainstream population could help address this tendency to overlook potential donor groups. More philanthropic studies that focus on specific nationality groups within a panethnic category would be useful, as they have different languages, histories, religious beliefs, reasons for migration, and levels of social adaptation that play a role in their willingness to donate to nonprofits (Agbayani-Siewert, 2004; Chao, 2001; Sundeen, Garcia, \& Roskoff, 2009).

Although literature on the field of philanthropy has examined why individuals give and how they do it, little attention has been paid to the acculturation process that occurs after immigrants' arrival to a host country and how that affects their charitable giving. This study focuses on two salient parts of the acculturation process - sociocultural adaptation and ethnic identity — and empirically examines their respective effects on giving. Using on data from the Korean-American Philanthropic Survey, we construct regression models to estimate such effects. A number of nonprofit managers and scholars regard Korean immigrants as important potential donors (Newman, 2002; Lee \& Moon, 2011). Korean immigrants are among the fastest growing Asian immigrant population and are considered by many to be "model minorities" due to their economic and educational success in the United States (Pettrey 2002). 
The following section provides a brief background to Korean immigrants in the United States. It also offers hypotheses pertaining to the effects of sociocultural adaptation and ethnic identity on giving. Then, the study outlines a research method that illustrates the data, variable measures, and empirical model. Finally, we present our findings and finish by discussing the limitations and implications of our study.

\section{KOREAN IMMIGRANTS IN THE UNITED STATES}

The Asian share of the total U.S. immigrant population rose sharply, from $0.7 \%$ to $3.8 \%$, between 1969 and 2004 (U.S. Census Bureau 2006), an effect of the Immigration and Nationality Act of 1965. The U.S. Census Bureau's 2005-2007 American Community Survey indicated that Korean immigrants were estimated to total 1.3 million, accounting for $4.5 \%$ of the U.S. immigrant population. They are known to be among the larger and fastest-growing Asian immigrant groups in the United States (Pettrey, 2002). In addition, Koreans are among the largest of Asian populations to obtain legal permanent residence in the past three decades. Between 19902007, about 350, 000 Korean-born immigrants secured legal permanent residence, which accounts for $2.0 \%$ of the 17.8 million immigrants who obtained legal permanent residence status in the United States during that time (U.S. Census Bureau, 2008). Currently, 32\% of Korean immigrants live in California; the next highest concentrations are found in New York, Illinois, New Jersey, and Texas, respectively (U.S. Census Bureau, 2010).

In addition, the educational success and economic prosperity of Korean immigrants can make them look attractive to nonprofit managers who seek financial support from an ethnic minority community. Korean immigrants are among the most highly educated people in the United States. According to the U.S. Census Bureau (2007), more than $51 \%$ of Korean-born immigrants have a bachelor's degree or higher, compared to approximately $49 \%$ of Asian Americans combined and $28 \%$ of the non-Hispanic white population. The median inflation-adjusted household income for Korean immigrants (foreign born and native combined) in 2007 was an estimated $\$ 52,729$, which surpassed that of the non-Hispanic white population by approximately $\$ 2,000$ (U.S. Census Bureau, 2007). 


\section{THE PROCESS OF ACCULTURATION}

The acculturation process involves social, cultural, and psychological change that occurs as immigrants adapt themselves to a new environment (Cabassa, 2003). Acculturation has been defined as being made up of "those phenomena which result when groups of individuals having different cultures come into continuous firsthand contact, with subsequent changes in the original cultural patterns of either or both groups" (Redfield, Linton, \& Herskovits, 1936, p. 149). At the individual level, acculturation refers to the process by which immigrants adapt themselves to the values, norms, attitudes, and behaviors of the dominant host culture (Berry, 1997). This process has been related to change in sociocultural behavior, as well as changes in ethnic identity.

There are two competing perspectives for conceptualizing this complex acculturation process. One camp (Cabassa, 2003; Gordon, 1964, 1995; Marin \& Gamba, 1996) supports a unidimensional model that conceptualizes the acculturation process as a movement along a single continuum, from a point at which immigrant's culture of origin remains fully intact to a point at the other end at which immigrant becomes fully assimilated into the host culture. The other camp claims that acculturation is an interactive, developmental, multidirectional, and multidimensional process that involves multiple modes of individual engagement in cultural adaptation (Berry, 1997, 2003; Cuellar, Arnold, \& Maldonado, 1995).

Berry (1997) considers two dimensions - sociocultural adaptation and ethnic identity - to characterize acculturation. The first refers to a set of external means by which individuals adapt to a new culture, including by learning new social skills and by learning about their new culture; the second is a set of internal responses to acculturation that describe psychological outcomes associated with individuals' sense of ethnic identity in their new cultural context. Although two dimensions are conceptually distinct, they are complementary in defining and characterizing different modes of acculturation. On the one hand, immigrants lose their original culture and ethnic identity as they come to fully accept host cultures. On the other, they may resist adaptation to a new culture while retaining their original ethnic identity. This cultural resistance may be related to "significant historical barriers (personal or otherwise) based on animosity and hatred toward the new culture" (Cuellar, Arnold, \& Maldonado, 1995, p. 279).

\section{Sociocultural Adaptation}

Sociocultural adaptation involves a behavioral shift in such areas as language 
use, interpersonal relationships, and food preferences. The level of adaptation depends on the extent of the contact and interaction of immigrants with a new culture, combined with their personality and sociohistorical background (Berry, 1997; Phinney et al., 2001).

The historical composition of Korean immigrants to the United States has varied; early immigrants were mainly recruited for cheap labor or had fled as political exiles, while the latest waves are skilled and educated white-collar workers who are employed mainly in the health and technology sectors. Although immigration experiences vary between old Korean immigrants and new ones as well as individually from immigrant to immigrant to another, they share initial hardships that result from language and cultural barriers and feelings of loneliness and isolation (Chao, 2001; Lee \& Moon, 2011). Such hardships are pronounced among Korean immigrants and can severely hamper their participation in the labor market of the United States.

As immigrants gradually adapt to American culture and society, they are presented with more opportunities to work and interact with others, which in turn can lead to financial and emotional stability that can function as a prerequisite to reaching out to help others (Chao, 2001; Putnam, 2000). In addition, sociocultural adaptation can immerse individuals in social networks through which they can then be contacted and recruited for philanthropic activities (Putnam, 2000). It is reasonable to assume that people who are asked are more likely to give and give more than those who are not. According to Putnam (2000), social relations are stronger indicators of giving than altruistic motives. These assumption allows us hypothesize that:

H1: Korean immigrants with a greater level of sociocultural adaptation are more likely to donate in the first place and more likely to donate higher amounts than those who are less well adapted.

\section{Ethnic Identity}

Ethnic identity is another salient aspect of the acculturation process. It is "a dynamic, multidimensional construct that refers to one's identity or sense of self as a member of an ethnic group" (Phinney et al., 2001, p. 2003). One's sense of ethnic identity is subject to change over time in a new culture. Change in the strength of ethnic identity is accompanied by changes in one's perceptions about the ethnic identity associated with one's native country (Berry, 1997; Cabassa, 2003; Cuellar, Arnold, \& Maldonado, 1995; Searle \& Ward, 1990).

Two contradictory claims can be made regarding the effect of ethnic identity on 
giving practices. On the one hand, a strong sense of ethnic identity contributes to socioeconomic success, known to be an important antecedent for giving. Several scholars (Fukuyama, 1993; Zhou, 2004, Zhou \& Kim, 2006) claim that ethnic identity and the cultural values that immigrants bring from their home country play a positive and significant role in socioeconomic advancement. In particular, the positive role of Asian cultural values and attitudes that emphasize "strong families, dutiful children, delayed gratification, education, hard work, discipline, respect for others and moral obligation to the community, and virtually all qualities that Americans prize and are now arguably losing" is widely acknowledged (Zhou, 2004, p. 147). It is also widely acknowledged that immigrants whose sense of ethnic identity is strong have a higher level of self-esteem and a sense of belonging. This psychological benefit also helps immigrants speed their incorporation into American society and achieve socioeconomic success (Zhou, 2004).Thus, we can hypothesize that:

H2a: Korean immigrants with a stronger sense of Korean identity are more likely to be donors and to donate more than Korean immigrants with a weaker ethnic identity

Conversely, it is possible that immigrants who retain a strong sense of ethnic identity are more likely to be ethnocentric and resistant to adapting to a new society and culture, which in turn could isolate them from mainstream society and culture. Such isolation could make it hard for them to access the resources (e.g., networks, social support) necessary to progress economically and to secure emotional stability, which in turn might diminish their interest in giving.

$\mathrm{H} 2 \mathrm{~b}$ : Korean immigrants with a stronger sense of Korean identity are less likely to be donors and to donate less than Korean immigrants with a weaker ethnic identity

\section{RESEARCH METHODS}

\section{Data}

This study uses a Korean American giving and volunteering survey conducted by the Dorothy A. Johnson Center for Philanthropy at Grand Valley State University and California State University, Fullerton. This survey that targets Korean immigrants in California was conducted during the spring of 2009. The questionnaire was 
prepared in both English and Korean and made accessible through the website of major Korean American news media organization. To facilitate participation, the survey was advertised through newspaper (both web and print) and radio commercials. The sample size was 748 Korean immigrants with legal residency in California. About $57 \%$ of the immigrants (423) had U.S. citizenship, 42\% (317) had permanent residency, and 1\% (8) had immigrant investor (EB-5) visas that grant permanent residency for a year or less.

\section{Dependent Variables}

To measure whether or not immigrants donated, we asked whether they gave to charitable organizations in 2008. Those who answered yes were given one point. Those who answered no were given zero points. Among the respondents, about $87 \%$ gave to organizations at least once a year. In addition, we measured how much they gave. Those who gave less than $\$ 1,000$ were given one point, those who gave between $\$ 1,000$ and $\$ 5,000$ were given two points, and those who gave more than $\$ 5,000$ were given three points.

\section{Independent Variables}

Sociocultural adaption was reverse scored and was measured using an additive index of multiple survey items pertaining to Korean immigrants' perception of changes in their sociocultural behaviors, including how much they spoke Korean at home, at work, and with friends, how much socializing they did with other Koreans, and how often they chose to eat Korean food. The correlations between these indicators confirmed that they can be considered a single factor. Cronbach's alpha was 0.72 , indicating that the index was reliable and accurately represented an underlying dimension associated with sociocultural adaptation.

Korean identity was measured by an additive index of multiple survey items regarding the level of immigrants' perceptions about Korean identity, commonality with Koreans in Korea and Koreans in America, the importance of being able to speak Korean, and the importance of preserving Korean culture. We confirmed that the high correlation between these measures and the index was reliable and represented a single dimension associated with this measure (Cronbach's alpha $=0.78$ ). We provide details about the survey questions and factor analysis results in table 2 . Both independent variable measures are based on a five-point Likert scale, with one representing "strongly disagree" and five "strongly agree." 
Table 1. Variable Coding

\begin{tabular}{|c|c|}
\hline Variables & Coding \\
\hline donor status & $\begin{array}{l}1=\text { respondent gives to a philanthropic organization; } \\
0=\text { respondent does not }\end{array}$ \\
\hline level of giving & $\begin{array}{l}1=\text { less than } \$ 1,000 ; 2=\text { between } \$ 1,000 \text { and } \$ 5,000 \\
3=\text { greater than } \$ 5,000\end{array}$ \\
\hline level of sociocultural adaptation & $\begin{array}{l}\text { combined scale constructed using values of the individual } \\
\text { survey items (for details, refer to table 2) }\end{array}$ \\
\hline strength of Korean Identity & $\begin{array}{l}\text { combined scale constructed using values of the individual } \\
\text { survey items (for details, refer to table 2) }\end{array}$ \\
\hline education level & $\begin{array}{l}0=\text { respondent does not hold a college degree; } \\
1=\text { respondent holds college degree; } 2=\text { respondent holds } \\
\text { graduate degree }\end{array}$ \\
\hline household Income & $\begin{array}{l}1=\text { less than } \$ 50,000 ; 2=\text { between } \$ 50,000 \text { and } \$ 100,000 \\
3=\text { greater than } \$ 100,000\end{array}$ \\
\hline marital status & $0=$ respondent is single; $1=$ respondent is married \\
\hline homeowner status & $1=$ respondent is a homeowner; $0=$ respondent is not \\
\hline employment status & $2=$ respondent is employed full time; $1=$ respondent is not \\
\hline parental status & $\begin{array}{l}1=\text { respondent has children living in household; } \\
0=\text { respondent does not }\end{array}$ \\
\hline $\begin{array}{l}\text { religiosity (frequency with which } \\
\text { respondents attend religious } \\
\text { services) }\end{array}$ & $\begin{array}{l}1=\text { respondent do not attend; } 2=\text { respondent attend only } \\
\text { major religious holidays; } 3=\text { respondent attends about once } \\
\text { a month; } 4=\text { respondent attends about once a week; } \\
5=\text { respondent attends more than once a week }\end{array}$ \\
\hline gender & $1=$ male; $0=$ female \\
\hline age & continuous variable \\
\hline immigration generation & $1=1$ st generation; $2=1.5$ generation \\
\hline length of time in the United States & $\begin{array}{l}1=\text { respondent has lived more than } 5 \text { years in the U.S.; } \\
0=\text { respondent has lived in the United States less than } 5 \\
\text { years }\end{array}$ \\
\hline
\end{tabular}


Table 2. Factor analysis of survey items (Principal Component Analysis, Promax).

\begin{tabular}{|c|c|c|}
\hline Items & $\begin{array}{l}\text { Socio-cultural } \\
\text { adaptation }\end{array}$ & $\begin{array}{l}\text { Korean } \\
\text { identity }\end{array}$ \\
\hline 1. How often do you speak Korean at home? (reversed) & 0.678 & 0.091 \\
\hline 2. How often do you speak Korean at work? (reversed) & 0.668 & -0.255 \\
\hline 3. How often do you speak Korean with your friends? (reversed) & 0.792 & -0.053 \\
\hline $\begin{array}{l}\text { 4. How much do you interact and associate with } \\
\text { Korean-Americans? (reversed) }\end{array}$ & 0.717 & 0.066 \\
\hline 5. How often do you eat Korean food at home? (reversed) & 0.607 & 0.205 \\
\hline 1. How much do you identify as a Korean? & -0.177 & 0.722 \\
\hline $\begin{array}{l}\text { 2. How much do you feel you have in common with Koreans } \\
\text { in Korea? }\end{array}$ & -0.070 & 0.559 \\
\hline $\begin{array}{l}\text { 3. How much do you feel you have in common with Koreans } \\
\text { in America? }\end{array}$ & -0.171 & 0.567 \\
\hline 4. How important is it for you to be able to speak Korean? & 0.027 & 0.808 \\
\hline 5. How important is it for you to preserve Korean culture? & 0.167 & 0.863 \\
\hline $\begin{array}{l}\text { Eigen Values } \\
\text { Percent of common variance } \\
\mathrm{N}=748\end{array}$ & $\begin{array}{l}4.013 \\
29.3\end{array}$ & $\begin{array}{l}1.913 \\
12.8\end{array}$ \\
\hline
\end{tabular}

To measure human resources, we used education attainment level and household income level. Education level is an ordinal variable that measures the highest level of education completed in either Korea and the United States or both as of 2008, ranging from two points for holding a graduate degree to one point for a college degree and zero points for no college degree. Household income is the ordinal variable that measures the total gross household income before taxes for 2008, ranging from three points for a household income greater than $\$ 100,000$ to two points for a household income between $\$ 50,000$ and $\$ 100,000$, and zero for a household income of less than $\$ 50,000$.

Social resources were measured by variables including marital status (Andreoni, Brown, \& Rischall, 2003; Mesch, Rooney, Steinberg, \& Denton, 2006), employment status (Frumkin, 2006; Sundeen, Garcia, \& Roskoff, 2009), homeownership status, and parental status (Wilson, 2000). Married respondents were given one point, and single respondents were given zero points. Employment status measured the current 
employment status of the respondents. Those with full-time employment were given two points; otherwise, they were given one point. Homeownership status measured the respondents' current housing situation. Those who owned a house were as awarded one point; otherwise, they earned zero points. Parental status measured the presence or absence of children living in the respondent's household. Respondents who had children in their households were given one point; otherwise, they received zero points.

Religiosity was measured by the frequency with which respondents attended religious services. Respondents who attended religious services more than once a week were given four points. Those who attended about once a week were given three points. Those who attended about once a month were given two points. Those who attended only on major religious holidays were given one point, and those who did not attend at all were given zero points.

\section{Control Variables}

To measure immigrant generation status, the respondents who were members of the 1.5 generation - those who were born outside the United States and immigrated as minors - were given one point. First-generation respondents - those who were born outside the United States and immigrated as adults - were given zero points. About $77 \%$ of the survey respondents in our sample indicated that they were first generation; 23\% were 1.5 generation. Years lived in the United States was measured by asking the respondents whether they had lived more than five years in the United States. Those who had lived in the United States for more than five years were given one point; otherwise, they received zero points. Five years is the minimum duration for acquiring citizenship after obtaining permanent residence status. These measures are typical proxies for measuring the level of exposure to a new society and culture and are known predictors of philanthropic activities (Ryder, Alden, and Paulhus, 2000; Sundeen, Garcia, and Raskoff, 2009).

Finally, we also included gender and age to measure the demographics of the respondents. Gender was measured by asking whether the respondents were male or female. Males were given one point, while females were given zero points. Approximately $33 \%$ of the respondents were female and $67 \%$ were male. Age was a continuous variable that ranged from 21 to 67 years old. 


\section{EMPIRICAL ANALYSES}

This study constructed both binary probit and ordered probit regression models to estimate both the determinants of immigrant donation and the level of donation, respectively. Table 3 offers descriptive statistics, and table 4 shows a frequency table. Table 5 provides both binary probit and ordered probit regression estimates of Korean immigrants' participation in and level of charitable giving in California.

Table 3. Descriptive Table

\begin{tabular}{l|c|c|c|c|c}
\hline \multicolumn{1}{c|}{ Variable } & Observations & Mean & $\begin{array}{c}\text { Standard } \\
\text { Deviation }\end{array}$ & Minimum & Maximum \\
\hline donor status & 748 & 0.878 & 0.327 & 0 & 1 \\
\hline level of giving & 748 & 1.182 & 0.450 & 1 & 3 \\
\hline $\begin{array}{l}\text { level of sociocultural } \\
\text { adaptation }\end{array}$ & 748 & 4.174 & 0.645 & 1.6 & 5 \\
\hline strength of Korean identity & 748 & 4.057 & 0.617 & 1.4 & 5 \\
\hline household income & 748 & 1.940 & 0.748 & 1 & 3 \\
\hline education level & 748 & 0.933 & 0.691 & 0 & 2 \\
\hline marital status & 748 & 0.821 & 0.384 & 0 & 1 \\
\hline homeownership & 748 & 0.492 & 0.500 & 0 & 1 \\
\hline employment status & 748 & 1.689 & 0.463 & 1 & 2 \\
\hline children living in household & 748 & 0.648 & 0.478 & 0 & 1 \\
\hline religiosity & 748 & 2.381 & 1.340 & 1 & 5 \\
\hline gender & 748 & 0.672 & 0.470 & 0 & 1 \\
\hline age & 748 & 43.961 & 10.213 & 21 & 76 \\
\hline immigration generation status & 748 & 1.234 & 0.424 & 1 & 2 \\
\hline length of time in the United & 748 & 0.940 & 0.238 & 0 & 1 \\
\hline States & & & & & 1 \\
\hline
\end{tabular}


Table 4. Frequency Table

\begin{tabular}{l|c}
\hline & $\begin{array}{c}\text { Donors (\%) } \\
88\end{array}$ \\
\hline $\begin{array}{l}\text { Household income } \\
\text { Less than } \$ 50,000\end{array}$ & 30 \\
between $\$ 50,000$ and $\$ 100,000$ & 44 \\
greater than $\$ 100,000$ & 26 \\
\hline Education & 26 \\
respondent does not hold a college degree & 52 \\
respondent holds a college degree & 22 \\
\hline respondent holds a graduate degree & \\
\hline Marital status & 83 \\
married & 17 \\
single & \\
\hline Homeownership status & 50 \\
respondent is a homeowner & 50 \\
\hline respondent is not & \\
\hline Employment status \\
respondent is employed full time & 68 \\
respondent is not & 32 \\
\hline Parental status & \\
respondent has children living in household & 65 \\
respondent does not & 35 \\
\hline Gender & 67 \\
male & 33 \\
\hline female & 93 \\
\hline Respondent has lived more than 5 years in the Us & \\
\hline & \\
\hline & \\
\hline
\end{tabular}


Table 5. Probit Regression Analyses

\begin{tabular}{|c|c|c|c|c|c|c|}
\hline & \multicolumn{3}{|c|}{ Participation in giving } & \multicolumn{3}{|c|}{ Lever of giving } \\
\hline & Coef. & Std. Err. & $\begin{array}{c}\text { Marginal } \\
\text { effect }\end{array}$ & Coef. & Std. Err. & $\begin{array}{c}\text { Marginal } \\
\text { effect }\end{array}$ \\
\hline $\begin{array}{l}\text { Sociocultural } \\
\text { Adaptation } \\
\text { (reversed) }\end{array}$ & -0.483 & $0.114^{\star \star \star}$ & -0.086 & -0.286 & $0.099^{\star \star}$ & 0.040 \\
\hline Korean identity & 0.396 & $0.111^{\star \star \star}$ & 0.070 & 0.055 & 0.107 & 0.008 \\
\hline Household income & 0.085 & 0.095 & 0.015 & 0.428 & $0.087^{\star \star \star}$ & 0.060 \\
\hline Educational level & 0.232 & $0.096^{\star \star}$ & 0.041 & 0.192 & $0.087^{*}$ & 0.027 \\
\hline Marital status(married) & -0.232 & 0.193 & -0.004 & -0.147 & 0.183 & 0.021 \\
\hline Home owner & -0.036 & 0.135 & -0.006 & -0.031 & 0.127 & 0.004 \\
\hline Employment status & -0.135 & 0.148 & -0.024 & -0.139 & 0.134 & 0.019 \\
\hline $\begin{array}{l}\text { Having children } \\
\text { in a household }\end{array}$ & 0.010 & 0.156 & 0.002 & -0.135 & 0.137 & 0.019 \\
\hline Religiosity & 0.092 & $0.045^{\star}$ & 0.016 & 0.180 & $0.05^{\star * \star}$ & 0.025 \\
\hline Gender(male) & -0.124 & 0.14 & -0.022 & -0.141 & 0.128 & 0.020 \\
\hline Age & 0.015 & $0.008^{*}$ & 0.003 & 0.008 & 0.006 & 0.001 \\
\hline Immigration generation & 0.149 & 0.176 & 0.027 & -0.195 & 0.164 & 0.028 \\
\hline $\begin{array}{l}\text { Lived more than } \\
5 \text { years in the US }\end{array}$ & 0.358 & 0.292 & 0.063 & 0.144 & 0.264 & 0.019 \\
\hline Constant & 1.352 & 0.833 & & & & \\
\hline Cut 1 & & & & 0.418 & 0.706 & \\
\hline Cut 2 & & & & 1.428 & 0.712 & \\
\hline \# observations & \multicolumn{2}{|c|}{748} & & \multicolumn{2}{|c|}{748} & \\
\hline$\chi^{2}$ & \multicolumn{2}{|c|}{46.89} & & \multicolumn{2}{|c|}{64.37} & \\
\hline probability $>\chi^{2}$ & \multicolumn{2}{|c|}{0.000} & & \multicolumn{2}{|c|}{0.000} & \\
\hline log like lihood & \multicolumn{2}{|c|}{-253.477} & & \multicolumn{2}{|c|}{-343.843} & \\
\hline
\end{tabular}

Note: ${ }^{*} p<0.05,{ }^{* \star} \mathrm{P}, 0.01,{ }^{* * *} \mathrm{p}<0.001$. 
Table 5 provides the empirical results. Both sociocultural adaptation and Korean identity are the positive and strongest predictors of immigrant participation in charitable giving $(\mathrm{p}<0.001)$, meaning immigrants who are more socially and culturally assimilated and who possess a stronger sense of Korean identity are more likely to donate than their counterparts. In terms of the level of giving, sociocultural adaptation is a positive and strong predictor $(p<0.001)$. Further strengthening of sociocultural adaptation increases the probability of participation in charitable giving by $8.5 \%$, and further strengthening of Korean identity increases the probability of participation by $7 \%$. Moreover, yet even further strengthening of sociocultural adaptation increases the likelihood by $4.04 \%$ on average that immigrants will increase the amount of their donation. However, strength of Korean identity is not statistically related to the level of giving. This insignificant result may be related to the fact that the level of giving is directly associated with the level of income (Frumkin, 2006).

The level of human resources available to immigrants are strong and positive predictors of giving. Both household income and education level are positively and significantly related to the level of giving at $\mathrm{p}<0.001$ and $\mathrm{p}<0.05$, respectively, although only education level is a predictor of participation $(\mathrm{p}<0.05)$. Korean immigrants with a higher level of education are $4.12 \%$ more likely to give to charitable organizations. In addition, immigrants with a higher level of household income and education are $1.74 \%$ and $0.08 \%$ more likely to increase the amount they donate to charitable organizations, respectively. However, the level of income is not significant with respect to participation in charitable giving. This insignificant result may be related to the fact that the decision to give is the result of a combination of factors, including education level and social pressure (Frumkin, 2006).

Social resources, including marital status, homeownership status, employment status, and parental status, are not significant at all either with respect to donating or to donation amount. These results are inconsistent with those of previous studies (Andreoni, Brown, \& Rischall, 2003; Frumkin, 2006; Mesch, Rooney, Steinberg, \& Denton, 2006; Sundeen, Garcia, \& Roskoff, 2009; Wilson, 2000) that suggest that people with greater social resources, which includes people who are married, people who are employed full time, homeowners, and people who have children living in their households, are more likely to have larger and broader social networks through which they are asked to give. A possible reason for this inconsistent finding might be related to the fact that immigrants don't possess the social resources, given language and cultural barriers, needed to access social networks in a host country. Social properties embedded in social resources that immigrants may bring with them when they emigrate are likely to not facilitate interaction with others in their new country. 
Religiosity is positively and significantly related both to participation in charitable giving $(\mathrm{p}<0.05)$ and the level of giving $(\mathrm{p}<0.001)$. More religious immigrants are $1.6 \%$ more likely to donate and $2.54 \%$ more likely to make a larger donation to charitable organizations, respectively.

Older immigrants are $0.3 \%$ more likely to give $(\mathrm{p}<0.05)$. However, age is not statistically related to the level of giving. This insignificant result may be explained by the fact that the level of giving is largely associated with the level of income (Frumkin, 2006).

Finally, immigration generation status and having lived more than five years in the United States are not significant in terms of explaining either participation in giving or level of giving. This insignificant result may be related to the fact that these variables cannot capture divergent patterns of adaptation. Adaptation is known to be the result of the interplay of combining factors, including socioeconomic backgrounds, settlement location, and networks of support (Zhou, 1997).

\section{CONCLUSION}

This study examines the influence of acculturation and ethnic identity on charitable giving practices among Korean immigrants in California. Our findings suggest that acculturation and ethnic identity indeed make a difference.

First, less being acculturated (keeping Korean sociocultural lifestyles rather than adopting American ones) has a negative influence on giving. Immigrants who are less familiar with American culture and society are less likely to give and less likely to give more. A lack of understanding of American culture and society may prevent Korean immigrants from being fully functional (e.g., working and socializing) in society. Economic and social viability is a condition conducive to giving (Chao, 2001). Also, being less acculturated means being less well connected to the community immigrants belong to, and the less well connected immigrants are, the less likely they are to be asked for donations.

Korean ethnic identity positively affected participation in giving, meaning immigrants with a stronger Korean identity were more likely to give. This result may have to do with Korean cultural values and attitudes emphasizing hard work, education, strong family connections, and discipline; values that are imbued with Confucianism are an important asset for immigrants in attaining socioeconomic success (Fukuyama, 1993; Zhou, 2004), which is considered a major factor in whether a person donates to charitable causes (Chao, 2001). Moreover, maintaining an identity as Korean or Korean American provides psychological and social bene- 
fits; it promotes a sense of self-esteem and belonging, as well as offers associational networks through which immigrants obtain emotional and social support they need to achieve socioeconomic stability.

Other measures often used as a proxy for acculturation such as number of years an immigrant has lived in the United States are statistically significant in terms of estimating philanthropic behaviors. First, the length of time an immigrant has lived in the United States (a measure of the level of exposure to a new culture) is an important determinant for giving. Immigrants who have lived longer in the United States are more likely to have a better understanding of and familiarity with American culture and society than their counterparts.

These findings have several important implications for nonprofits who want to reach out to Korean immigrants for philanthropic donations. First, the current fundraising strategies that merely emphasize soliciting for donations from immigrants will not work. Rather, nonprofits need to be strategic about whom they ask and how to garner more philanthropic support from immigrants. In the short run, nonprofits' fundraising efforts should be directed more toward targeted immigrant groups than the general immigrant population. Those who interact with and are assimilated into mainstream culture and society would be better targets for solicitation. In addition, nonprofits need to build more trustful and reciprocal relationships with immigrant communities by making a commitment to assist immigrants in both adapting to American culture and society and preserving distinctive cultural values. It is more likely that such assistance can be provided by nonprofits' partnering with and supporting ethnic-based organizations. One area where nonprofits could play a significant role is in building bridges between minorities and the mainstream population; nonprofits could become cultural and social epicenters where people from different backgrounds and cultures have the opportunity to interact and socialize, which ultimately promotes trust and cooperation. Nonprofits could also partner with ethnic-based nonprofits to facilitate and promote cultural events that would allow immigrants to feel proud of their distinctive cultural heritage and values and share them with the mainstream population. This new role for nonprofits would contribute to breaking the cycle of immigrants associating primarily with people of their own kind, which creates stronger ties to their ethnic-based groups, and helping promote broader dimensions of civic engagement.

This study is not without limitations. The first major limitation is related to the web-based survey method. This method can introduce a sampling bias, which would prevent our empirical results from being generalized to the general population of Korean immigrants in California. To increase the credibility and validity of the results, future studies should obtain data from multiple data sources, including 
interviews and primary research. Second, the scope of this study is limited to Korean immigrants in California. It would be interesting to compare Korean immigrants and other Asian immigrants with similar cultural values, including Chinese and Vietnamese. Third, to develop hypotheses linking sociocultural adaptation with giving, this study adopted the assimilation perspective. This assimilation perspective, however, does not fully take account of divergent philanthropic behavior that arises from distinct patterns of adaptation and anomalies (segmented assimilation) likely to occur among immigrants (Zhou, 1997). Future studies need to address segmented assimilation.

There are several areas concerning the pattern of philanthropic giving behaviors among Korean immigrants in the United States that warrant further study. First, future studies could investigate how a pattern of giving evolves with the progression of acculturation. In particular, it is important to differentiate the impact that acculturation has on two discrete philanthropic giving practices: mainstream giving (directed toward the general U.S. population) and ethnic-based giving (tailored to ethnic-based causes). It would also be interesting to examine whether patterns of giving expand from ethnic-based giving to mainstream giving as the acculturation process advances. Our current study is not clear about the impact of acculturation on such discrete philanthropic giving practices. Second, it would be interesting to examine immigrants' participation in informal giving practices and compare it with participation in formal giving practices both within a specific Korean group and across Asian groups in the United States. Research on philanthropy suggests that African Americans have a long tradition of informal philanthropy (Van Slyke, Ashley, and Johnson, 2007; Hall-Russell and Kasberg, 1997). Another important question would be whether patterns of giving expand from informal to formal giving practices as acculturation progresses.

\section{REFERENCES}

Alba, R., \& Nee, V. 2003. Remaking the American mainstream: Assimilation and contemporary immigration. Cambridge, MA: Harvard University Press.

Agbayani-Siewert, P. 2004. Assumptions of Asian-American similarity: The case of Filipino and Chinese American students. Social Work, 49(1): 39-51.

Andreoni, J., Brown, E., \& Rischall, I. 2003. Charitable giving by married couples: Who decides and why does it matter? Journal of Human Resources, 38(1): 111133. 
Andreoni, J., Gale, W. G., \& Scholz, J. K. 1996. Charitable contributions of time and money. July 1996. Retrieved on January 21, 2009, http://econ.ucsd.edu/ jandreon/WorkingPapers/ags-v8.pdf.

Anft, M., \& Lipman, H. 2003. How Americans give. Chronicle of Philanthropy, 15(14): 6-10.

Berry, J. W. 1997. Immigration, acculturation, and adaptation. Applied Psychology: An International Review, 46(1): 5-68.

Berry, J. W. 2003. Conceptual approaches to acculturation. In K. M. Chun, P. B. Organista, \& G. Marin (eds.), Acculturation: Advances in theory, measurement, and applied research (pp. 17-38). Washington, DC: American Psychological Association.

Brown, E. 1999. Patterns and purposes of philanthropic giving. In C. T. Clotfelter \& T. Ehrlich (eds.), Philanthropy and the nonprofit sector (pp. 212-230). Bloomington: Indiana University Press.

Brown, E. 2001. Making philanthropy work: Social capital and human capital as predictors of household giving. Claremont Colleges Working Papers in Economics.

Brown, E. 2005. Married couples' charitable giving: Who and why. New Directions for Philanthropic Fundraising, 50:69-80.

Bryant, W. K, Slaughter, H.-J., Kang, H., \& Tax, A. 2003. Participating in philanthropic activities: Donating money and time. Journal of Consumer Policy, 26(1): 43-73.

Cabassa, L. J. 2003. Measuring acculturation: Where we are and where we need to go. Hispanic Journal of Behavioral Sciences, 25(2): 127-146.

Chao, J. 1999. Asian-American philanthropy: Expanding circles of participation. In J. Scanlon (ed.), Cultures of caring: Philanthropy in diverse American communities (pp. 197-253). Washington, DC: W. K. Kellogg Foundation, David and Lucile Packard Foundation, and the Council on Foundations.

Chao, J. 2001. Asian-American philanthropy: Acculturation and charitable vehicles. In P. C. Rogers (ed.), Philanthropy in communities of color: Traditions and challenges (pp. 57-79). Indianapolis, IN: ARNOVA.

Clotfelter, C. T. 1997. The economics of giving. In J. W. Barry \& B. V. Manno (eds.), Giving better, giving smarter: Working papers of the National Commission on Philanthropy and Civic Renewal (pp. 31-55). Washington, DC: National Commission on Philanthropy and Civic Renewal.

Cuellar, I., B. Arnold, B., \& Maldonado, R. 1995. Acculturation rating scale for Mexican American-II: A revision of the original ARSMA scale. Hispanic Journal of Behavioral Sciences, 17(3): 275-304. 
Dillman, D. A. 2007. Mail and internet surveys: The tailored design method (2nd ed.). Hoboken, NJ: John Wiley and Sons.

Dillman, D. A., Tortora, R. D., Conrad J., \& Bowker, D. 1998. Influence of plain versus fancy design on response rates of web surveys. Unpublished paper. Retrieved on June 15, 2009, www. sesrc.wsu.edu/dillman'spapers.htm.

Feldstein, M., and Clotfelter, C. T. 1976. Tax incentives and charitable contribution in the United States: A microeconomic analysis. Journal of Public Economics, 5(1):1-26.

Frumkin, P. 2006. Strategic giving: The art and science of giving. Chicago: University of Chicago Press.

Fukuyama, F. 1993. Immigrants and family values. Commentary, 95(5): 26-32.

Gittell, R., \& Tibal, E. 2006. Charitable giving: Factors influencing giving in U.S. States. Nonprofit and Voluntary Sector Quarterly, 35(4): 721-736.

Giving USA. 2009. Giving USA: The annual report on philanthropy for the year 2008. Indianapolis: Center on Philanthropy at Indiana University.

Gordon, M. M. 1964. Assimilation in American life. New York: Oxford University Press.

Gordon, M. M. 1995. Assimilation in America: Theory and reality. In A. Aguire \& E. Baker (eds.), Notable selection in race and ethnicity (pp. 91-101) Guilford, CT: Dushkin.

Hall-Russell, C., \& Kasberg, R. H. 1997. African American traditions of giving and serving: A Midwest perspective. Indianapolis: Center on Philanthropy at Indiana University Center.

Hodgkinson, V. A. 2002. Individual giving and volunteering. In L. M. Salamon (ed.), The state of nonprofit America (pp. 387-420). Washington, DC: Brookings Institution Press.

Hodgkinson, V. A., \& Weitzman, M. 1996. Giving and volunteering in the United States. Washington, DC: Independent Sector.

Jencks, C. 1987. Who gives to what? In W. W. Powell (ed.), The nonprofit sector (pp. 321-339). New Haven, CT: Yale University Press.

Johnson, A. S. 2011. Korean American philanthropy: Traditions, trends, and potential. San Francisco, CA: Give2Asia.

Lee, J.-Y., \& Moon, S.-G. 2011. Mainstream and ethnic volunteering by Korean immigrants in the United States. Voluntas: International Journal of Voluntary and Nonprofit Organizations, 22(4): 811-830.

Marin, G., \& Gamba, R. J. 1996. A new measurement of acculturation for Hispanics: The bidimensional acculturation scale for Hispanics (BAS). Hispanic Journal of Behavioral Science, 18(3): 297-316. 
Mesch, D. J., Rooney, P. M., Steinberg, K. S., \& Denton, B. 2006. The effects of race, gender, and marital status on giving and volunteering in Indiana. Nonprofit and Voluntary Sector Quarterly, 35(4): 565-587.

Mills, R. S., Pedersen, J., \& Grusec, J. E. 1989. Sex differences in reasoning and emotion about altruism. Sex Roles, 20(11/12): 603-621.

Min, P.-G. 1992. The structure and social functions of Korean immigrant churches in the United States. International Migration Review 26(3): 1370-1394.

Min, P.-G. 2001. Changes in Korean immigrants' gender role and social status, and their marital conflicts. Sociological Forum 16(2): 301-320.

Moon, S.-G., \& Choi, S. O. 2012. Ethnic giving versus mainstream giving by foreign-born Korean immigrants in California. Nonprofit and Voluntary Sector Quarterly, 20(10): 1-25.

Moon, S.-G., \& Downey, M. 2011. Philanthropic motives: The "who" and "why" of charitable giving and volunteering. In K. Agard (ed.), Nonprofit leadership handbook (pp. 781-788). Thousand Oaks, CA: Sage.

Newman, D. S. 2002. Opening doors: Pathways to diverse donors. San Francisco: Jossey-Bass.

O'Flannery, E. 1961. Social and cultural assimilation. American Catholic Sociological Review, 22(3): 195-206.

Pettrey, J. G. 2002. Cultivating diversity in fundraising. New York: John Wiley and Sons.

Phinney, J. S. 2003. Ethnic identity and acculturation. In K. M. Chun, P. B. Organista, \& G. Marin (eds.), Acculturation: Advances in theory, measurement, and applied research (pp. 63-81). Washington, DC: American Psychological Association.

Phinney, J. S., Horenczyk, G., Liebkind, K., \& Vedder, P. (2001). Ethnic identity, immigration, and well-being: An interactive perspective. Journal of Social Issues 57(3): 493-510.

Putnam, R. D. 1995. Bowling alone: America's declining social capital. Journal of Democracy, 6(1): 65-78.

Putnam, R. D. 2000. Bowling alone: The collapse and revival of American community. New York: Simon and Schuster.

Redfield, R., Linton, R., \& Herskovits, M. J. 1936. Memorandum for the study of acculturation. American Anthropologist, 38(1): 149-152.

Ryder, A. G., Alden, L. E., \& Paulhus, D. L. 2000. Is acculturation unidimensional or bidimensional? A head to head comparison in the prediction of personality, self-identity, and adjustment. Journal of Personality and Social Psychology, 79(1): 49-65. 
Salabarria-Pena, Y., Trout, P. T., Gill, J. K., Morisky, D. E., Muralles, A. A., \& Ebin, V. J. 2001. Effects of acculturation and psychosocial factors in Latino adolescents' TB-related behaviors. Ethnicity and Disease 11(4): 661-675.

Salamon, L. M. 2002. The resilient sector: The state of nonprofit America. In L. M. Salamon (ed.), The State of Nonprofit America (pp. 3-61). Washington, DC: Brookings Institution Press.

Schervish, P. G., \& Havens, J. J. 1995. Wherewithal and beneficence: Charitable giving by income and wealth. New Directions for Philanthropic Fundraising, 8:81109.

Searle, W., and Ward, C. 1990. The prediction of psychological and sociocultural adjustment during cross-cultural transitions. International Journal of Intercultural Relations 14(4): 449-464.

Shao, S. 1995. Asian American giving: Issues and challenges. New Directions for Philanthropic Fundraising, 8:53-64.

Smith, B., Shue, S., Vest, J. L., \& Villarreal, J. 1999. Philanthropy in communities of color. Bloomington: Indiana University Press.

Sundeen, R. A., Garcia, C., \& Raskoff, S. A. 2009. Ethnicity, acculturation, and volunteering to organizations: A comparison of African Americans, Asians, Hispanics, and whites. Nonprofit and Voluntary Sector Quarterly, 38(6): 929-955.

U.S. Census Bureau. 2006. American community survey. Washington, DC: Government Printing Office.

U.S. Census Bureau. 2007. American community survey. Washington, DC: Government Printing Office.

U.S. Census Bureau. 2008. American community survey. Washington, DC: Government Printing Office.

U.S. Census Bureau. 2010. American community survey. Washington, DC: Government Printing Office.

Uslaner, E. M., \& Conley, R. S. 2003. Civic engagement and particularized trust: The ties that bind people to their ethnic communities. American Politics Research, 31(4): 331-360.

Van Slyke, D. M., Ashley, S., and Johnson, J. L. 2007. Nonprofit performance, fund-raising effectiveness, and strategies for engaging African Americans in philanthropy. American Review of Public Administration, 37(3): 278-305.

Wilson, J. 2000. Volunteering. Annual Review of Sociology, 26:215-40.

Zhou, M. 1997. Segmented assimilation: Issues, controversies, and recent research on the new second generation. International Migration Review, 31(4): 975-1009.

Zhou, M. 2004. Assimilation, the Asian way. In Tamar Jacoby (ed.), Reinventing the melting pot: The new immigrants and what it means to be American (pp. 139- 
153). New York: Basic Books.

Zhou, M., \& Kim, S. S. 2006. Community forces, social capital, and educational achievement: The case of supplementary education in the Chinese and Korean immigrant communities. Harvard Educational Review, 76(1): 1-29. 